University of Montana

ScholarWorks at University of Montana

$12-2004$

\title{
Loss of Enemy Resistance Among Introduced Populations of St. John's Wort (Hypericum Perforatum)
}

John L. Maron

University of Montana - Missoula, john.maron@mso.umt.edu

Montserrat Vilà

John Arnason

Follow this and additional works at: https://scholarworks.umt.edu/biosci_pubs

Part of the Biology Commons

Let us know how access to this document benefits you.

\section{Recommended Citation}

Maron, John L.; Vilà, Montserrat; and Arnason, John, "Loss of Enemy Resistance Among Introduced Populations of St. John's Wort (Hypericum Perforatum)" (2004). Biological Sciences Faculty Publications. 239.

https://scholarworks.umt.edu/biosci_pubs/239

This Article is brought to you for free and open access by the Biological Sciences at ScholarWorks at University of Montana. It has been accepted for inclusion in Biological Sciences Faculty Publications by an authorized administrator of ScholarWorks at University of Montana. For more information, please contact scholarworks@mso.umt.edu. 


\title{
LOSS OF ENEMY RESISTANCE AMONG INTRODUCED POPULATIONS OF ST. JOHN'S WORT (HYPERICUM PERFORATUM)
}

\author{
John L. Maron,,${ }^{1,4}$ Montserrat Vilà, ${ }^{2}$ And John Arnason ${ }^{3}$ \\ ${ }^{1}$ Division of Biological Sciences, University of Montana, Missoula, Montana 59812 USA \\ ${ }^{2}$ Centre de Recerca Ecològica i Aplicacions Forestals, Universitat Autònoma de Barcelona, 08193 Bellaterra, Spain \\ ${ }^{3}$ Biology Department, Box 450, Station A, University of Ottawa, Ontario, Canada K1N 6N5
}

\begin{abstract}
The Evolution of Increased Competitive Ability (EICA) hypothesis predicts that introduced plants should lose enemy resistance and in turn evolve increased size or fecundity. We tested the first prediction of this hypothesis by growing introduced North American and native European genotypes of St. John's Wort (Hypericum perforatum) in common gardens in the state of Washington, USA, and in Girona, Spain. In both gardens we measured levels of hypericin and pseudohypericin (and in Washington, hypericide) compounds known to be toxic to generalist pathogens and herbivores. In a third common garden, in Spain, we experimentally manipulated native pathogen pressure (by treating plants with fungicides) and quantified how pathogen resistance varied between North American and European genotypes.

North American St. John's Wort had lower levels of hypericin than European conspecifics in common gardens in Washington and Spain. North American plants also produced less hypericide (in Washington) and pseudohypericin (in Spain) than did European plants. In Spain, individuals were attacked by three generalist pathogens: Colletotrichum sp. (Coelomycetes), Alternaria sp. (Hyphomycetes), and Fusarium oxysporum (Hyphomycetes). A higher percentage of individuals from North American populations were infected by pathogens and died from pathogen attack compared to European genotypes. Infection also appeared to reduce plant size and fecundity; these negative effects were similar in magnitude for North American and European genotypes. Taken together, results indicate that introduced St. John's Wort has lost enemy resistance. However, contrary to EICA, current and previous results indicate that these changes have not been associated with an increase in plant size or fecundity.

Key words: EICA hypothesis; exotic plants; Hypericum perforatum; loss of resistance; rapid evolution; St. John's Wort.
\end{abstract}

\section{INTRODUCTION}

Plants introduced to new regions are often liberated from their natural enemies (Wolfe 2002, Mitchell and Power 2003, DeWalt et al. 2004). Since these enemies can be quite damaging (Crawley 1997, Packer and Clay 2000, Klironomos 2002, DeWalt et al. 2004), it has long been thought that the absence of enemy attack may enable nonnatives to gain a competitive advantage over natives, allowing them to become dominant in recipient communities (Elton 1958, Mack et al. 2000, Maron and Vilà 2001, Keane and Crawley 2002). Recent tests of this theory suggest that escape from soil pathogens, in particular, may be important for exotic plant success (Mitchell and Power 2003, Reinhart et al. 2003; but see Beckstead and Parker 2003).

Blossey and Nötzold (1995) proposed that reduced enemy attack on nonnative plants ought to promote an evolutionary change in the phenotype of exotics. Because resistance traits can be energetically costly (Ber-

\footnotetext{
${ }^{4}$ E-mail: john.maron@mso.umt.edu
}

gelson and Purrington 1996, Strauss et al. 2002) and selection on these traits may be relaxed in the introduced range, the Evolution of Increased Competitive Ability (EICA) hypothesis predicts that plants from nonnative populations should lose enemy resistance. In turn, the hypothesis predicts that nonnatives should reallocate resources previously spent on defense to other functions that might be at a selective premium in the introduced range, such as increased growth or fecundity (Blossey and Nötzold 1995). These traits are thought to contribute to the overall competitive superiority of exotics over natives in the introduced range.

While this explanation for invasiveness is intriguing, definitive tests of the EICA hypothesis are still scarce. One approach to testing EICA has been to compare the preference of pests on plant genotypes from the native and introduced range. Siemann and Rogers (2003) showed that in a greenhouse, generalist grasshoppers preferred nonnative over native genotypes of Chinese Tallow Tree (Sapium sebiferum) seedlings. In a similar greenhouse experiment, Daehler and Strong (1997) found that specialist planthoppers (Prokelisia marginata) were more damaging to nonnative cordgrass (Spar- 
tina alternaflora) that had a history of low planthopper herbivory compared to either native or nonnative genotypes that had historically received heavy herbivory by planthoppers. Although these studies strongly suggest that nonnative plants may lose resistance to enemies in the introduced range, a definitive test of the EICA hypothesis involves growing nonnative and native genotypes side by side in the native range, to determine if introduced plants have reduced defenses, suffer more attack, and incur greater damage by native natural enemies compared to their native conspecifics.

An alternative to the EICA hypothesis is the Enemy Release Hypothesis. This hypothesis suggests that nonnatives faced with reduced enemy pressure simply alter investment in defensive chemistry in a plastic manner, without undergoing any genetically based change in resistance (Bazzaz et al. 1987). If this is the case, natives and nonnatives grown together in common gardens would not exhibit differences in enemy resistance. We know of no study that has employed reciprocal common gardens to examine the degree to which variation in defensive chemistry between native and exotic conspecifics is due to plasticity (as predicted by the Enemy Release Hypothesis) vs. genetically based evolutionary changes (as predicted by EICA). Furthermore, no one has yet determined whether nonnatives suffer greater reductions in fitness from enemy attack compared to native conspecifics when both are grown in the native range.

Here we test whether exotic North American populations of the noxious weed, St. John's Wort (Hypericum perforatum L., Hypericaceae), have lower levels of genetically based defensive chemicals and pathogen resistance than native conspecifics from European populations. To compare defensive chemistry between native and introduced plants we grew individuals from introduced North American and native European populations in reciprocal common gardens in the state of Washington, USA, and in Spain. We assayed levels of three major secondary compounds (i.e., hypericin, pseudohypericin, and hypericide) in leaf tissue from these plants. These compounds are known to exhibit strong antimicrobial properties that can provide defense against pathogens (Arnason et al. 1983); they deter many generalist insect herbivores (Arnason et al. 1983, 1992, Fields et al. 1990, Mitich 1994, Sirvent et al. 2003), and are toxic to mammals (Giese 1980). By assaying levels of these compounds in reciprocal gardens, we could explicitly determine whether variation in defensive chemistry was due to plasticity or genetically based differences between native and introduced plants. To explore whether nonnative genotypes have lost resistance to their native pathogens, we experimentally manipulated exposure to pathogens and compared the frequency of pathogen attack and the fitness consequences of this attack on native and introduced St. John's Wort in a third common garden, in Spain.

\section{St. John's Wort natural history}

St. John's Wort is a perennial forb native to Europe, North Africa, and Asia that has been introduced into many regions throughout the world, including North and South America, Australia, New Zealand, and South Africa. As an exotic, St. John's Wort often occurs in dense monospecific stands where it grows in disturbed sites, along roadsides, in overgrazed rangeland, or in abandoned fields.

St. John's Wort produces the secondary compounds hypericin and pseudohypericin in its leaves and inflorescences. These naphthodianthrones (Trifunovic et al. 1998) are powerful photooxidants activated by visible light of $590 \mathrm{~nm}$ wavelength. When activated, hypericin causes lipid peroxidation and generates singlet oxygen that damages cells. This can be fatal to phytophagous insects and mammals (Giese 1980, Arnason et al. 1983, 1992, Knox and Dodge 1985, Fields et al. 1990, Mitich 1994) and increases resistance to pathogens (Arnason et al. 1983).

\section{Methods}

\section{Genetically based differences in defensive chemistry between introduced and native genotypes}

In late summer 1998 and 1999 we collected mature seed capsules of $H$. perforatum from at least 10 individuals from 18 source populations across Europe, 18 source populations from western North America, and 14 source populations across central North America (see Appendix). Seed collection methods are outlined in Maron et al. (2004).

We established common gardens in an old field in Snohomish, Washington (latitude $47^{\circ} 52^{\prime} \mathrm{N}$ ) and at the Mas Badia Experimental Field Station (IRTA) near Girona, Spain (latitude $42^{\circ} 19^{\prime}$ N). See Maron et al. (2004) for climate comparisons between these sites. The Washington garden contained plants from all 50 source populations, whereas the Spain garden contained plants from 42 populations (16 European and 26 North American populations). In Spain, 10 individuals from each source population (except those populations where seeds were collected as a pooled sample) were sibs of those planted in Washington; others were collected from additional maternal plants in each population. St. John's Wort produces upwards of $90 \%$ of its seed apomictically, therefore maternal sibs planted across gardens were likely clones (Arnholdt-Schmitt 2000, Mayo and Langridge 2003). Plants were germinated from seed and grown in greenhouses at the Universities of Washington and Barcelona prior to transplantation into mowed and tilled plots in each garden in May (Washington) and June (Spain) of 2000.

In Washington, we established ten $8.5 \mathrm{~m} \times 12 \mathrm{~m}$ blocks composed of six $1.5 \mathrm{~m} \times 12 \mathrm{~m}$ plots separated by $2 \mathrm{~m}$. Plants in three of these plots were exposed to herbivory by Chrysolina quadrigemina Suffr (Coleoptera: Chrysomelidae) as part of a separate experiment 
not discussed here. Each of the three plots within a block contained plants from a different region; within blocks, we planted one individual from each population within one region (Europe, western North America, central North America). Across blocks, plots contained a unique individual from each population. Plots consisted of two rows of nine individuals (spaced $1.5 \mathrm{~m}$ apart). In Spain, we randomly assigned an individual from each population within a region to one of fourteen $4 \mathrm{~m} \times 4 \mathrm{~m}$ plots (42 plots total). Individuals within plots were separated by $1 \mathrm{~m}$ and plots were separated by $2.5 \mathrm{~m}$.

In June 2001 , we collected $\sim 5$ g of healthy leaves from the upper stems of $2-7$ (mean $=4.7)$ individuals from each population grown in Spain. In June 2002 , we similarly sampled leaf tissue from 5-7 (mean = 6.2) individuals from each population grown in Washington. In both gardens, plants had little herbivore damage at the time of leaf harvest.

\section{Chemical analyses}

Leaf tissue was analyzed for hypericin, pseudohypericin, and hypericide (hypericide was only assayed from tissue collected in Washington). Hypericide is a flavone that likely has mild antimicrobial properties (USDA-ARS photochemical data base, available online). ${ }^{5}$ Leaves were air dried and ground to a powder with a Wiley Mill fitted with a 40 size mesh. Approximately $0.2 \mathrm{~g}$ of powder was extracted four times with $9 \mathrm{~mL}$ of $60 \%$ Acetone. Each extraction was accomplished in an ultrasonic bath ( $5 \mathrm{~min})$, followed by centrifugation $\left(3 \mathrm{~min}\right.$ at $\left.9800 \mathrm{~m} / \mathrm{s}^{2}\right)$. Supernatants of the four extractions were pooled and brought to a total volume of $40 \mathrm{~mL}$. Five $\mathrm{mL}$ of each sample was filtered through a $0.22-\mu \mathrm{L}$ PTFE (polytetrafluoro-ethylene) membrane and injected into a HPLC equipped with a $3-\mu \mathrm{m}$ LiChrosper $10075 \mathrm{~mm} \times 4.6 \mathrm{~mm}$ analytical cartridge (Agilent Technologies, Mississauga, Ontario, Canada). The identity of hypericin was confirmed by comparing spectral analyses and retention time relative to a hypericin standard obtained from B. Foster, Therapeutic Products Branch, Health Canada. (The standard was $>95 \%$ purity as measured by HPLC.) Extracts were analyzed for hypericide using a Zorbax Eclipse XDB-C-8 column (Agilent, Mississauga, Ontario, Canada; $4.6 \mathrm{~mm} \times 190 \mathrm{~mm}, 5 \mu \mathrm{m})$ using a gradient three solvent system (A:B:C $=$ MeOH:MeCN:25mM $\mathrm{NaH}_{2} \mathrm{PO}_{4}$ buffer, $\mathrm{pH} 3.0$ ). The solvent program was as follows: $\mathrm{A}: \mathrm{B}: \mathrm{C}=0: 5: 95$ at $0 \mathrm{~min}, 10: 20: 70$ at $15 \mathrm{~min}$, $15: 75: 10$ at $20 \mathrm{~min}, 15: 80: 5$ at $22 \mathrm{~min}, 0: 15: 85$ at 23 min, and 0:5:95 at $25 \mathrm{~min}$. Hypericide was detected at a retention time of $12.3 \mathrm{~min}$ at $270 \mathrm{~nm}$.

\section{Data analysis-defensive chemistry}

We used ANOVA to compare levels of secondary compounds among native and introduced St. John's

\footnotetext{
${ }^{5}\langle$ http://www.ars-grin.gov/duke/ $\rangle$
}

Wort, first analyzing data from each garden separately. Both continent of origin (fixed factor) and source population nested within continent of population origin (random factor) were main effects in this analysis. The continent effect tested whether North American plants differed in defensive chemistry from European genotypes. Originally, we intended to also test whether nonnative western and central North American genotypes differed in their levels of defense, since plants from these two regions have different histories of exposure to biological control (Maron et al. 2004). However, since preliminary analyses revealed no significant differences in hypericin, pseudohypericin, or hypericide between plants from these regions we combined all North American data prior to analysis.

In a second analysis, we combined data from both gardens so that we could examine levels of plasticity in secondary defensive chemistry. Here, we only used data from putative clones present in both gardens, omitting data from individuals grown in one garden but not the other. We used a two-way ANOVA to test the effect of garden location and continent of population origin (both fixed factors), population nested within continent (a random factor), continent $\times$ garden and population nested within continent $\times$ garden interactions on hypericin and pseudohypericin concentrations. In both the first and second analyses, the continent of origin effect was tested over the population nested within continent error term, since population is a random effect. A significant effect of garden means that there is phenotypic plasticity, with defensive chemistry varying between gardens. A significant continent $\times$ garden interaction indicates that native and nonnative genotypes differ in the degree of plasticity for defensive chemistry. These and all other analyses were performed using SYSTAT Version 10.0 (SYSTAT 2000).

\section{Genetically based differences in resistance to native pathogens between introduced and native genotypes}

To determine how pathogen infection and the fitness consequences of infection varied between European and North American St. John's Wort, in 2002 we established a third common garden at the Universitat Autònoma de Barcelona campus field station in Bellaterra (Barcelona), Spain. This garden contained plants from 30 source populations, 15 each from Europe and western North America (we omitted central North American populations due to space limitations). We propagated plants in the University of Barcelona greenhouse and after 13 weeks we outplanted seedlings in May 2002. All seedlings were watered after planting and again one week later. We established forty $4.5 \mathrm{~m} \times 3 \mathrm{~m}$ experimental plots, with each plot spaced $2 \mathrm{~m}$ apart. Each plot contained 15 plants (one individual from each population within a given region; plants spaced $0.75 \mathrm{~m}$ apart). Plants in half of the plots (i.e., 20) were exposed to ambient levels of pathogens; we suppressed pathogen attack on plants in the remaining 20 plots by spray- 
ing the plants and the ground in a $10 \mathrm{~cm}$ radius around each plant with fungicide. Replicate plots within a treatment contained different individuals from the same populations. Pairs of treated and control plots contained plants collected as seed from the same mother; these plants were likely clones. We periodically hand clipped vegetation around plants to prevent surrounding grasses and forbs from overgrowing experimental plants.

Fungicide application started in April 2003 and was applied every two weeks through July 2003. The fungicides fosetil Al (commercial name: Alliette, Aventis CropScience España S.A., Alcacer [Valencia]) and Benomyl (commercial name: Benlate, du Pont Iberica, S.A., Barcelona, Spain) were alternated so fungi would not become resistant to the treatments. In the last two applications (July 2003), due to the risk of high fungal infection after hot and rainy weather, we used contact fungicides Bitertanol + Ziram (commercial name: Baycor Z, Bayer Hispania S.A., Barcelona, Spain) instead of the systemic fungicides. For each fungicide, we followed the recommended commercial doses $(2.42 \mathrm{~g}$ active ingredient/L water for fosetil $\mathrm{Al}, 0.91 \mathrm{~g}$ active ingredient/L water for Benomyl, and $0.04 \mathrm{~g}$ Bitertanol $+0.73 \mathrm{~g}$ Ziram $/ \mathrm{L}$ water). Control plants were treated with water to control for the water received by plants treated with fungicide. All of these fungicides have broad spectrum effects. Although Benomyl is a recommended method for reducing soil fungi in experiments with plants (Fitter and Nichols 1988, Smith et al. 2000), it kills not only pathogenic fungi but a wide range of fungal types (West et al. 1993, Newsham et al. 1994).

During the first summer young plants remained pathogen free and very few individuals produced seed capsules (35 out of 600 or $6 \%$ ). Starting in January 2003, we censused plants every two weeks, noting pathogen infection. Pathogen infection was easily diagnosed; infected plants had reddish necrotic foliage and stems. This symptom could remain, spread upward through the infected stem in a few days, and extend to the whole plant in a few weeks, killing infected individuals. To determine the identity of the pathogens associated with these symptoms we harvested six infected plants and immediately cultured the pathogens from harvested tissue on potato dextrose agar (PDA). Cultured pathogens were identified with the aid of an optical microscope.

Infection was caused by three pathogen taxa: Colletotrichum sp. (Coelomycetes), Alternaria sp. Nees (Hyphomycetes), and Fusarium oxysporum (Hyphomycetes). These generalist soil fungal pathogens are dispersed by water (Andrés et al. 1998) and cause necrosis (or anthracnose in the case of Colletotricum). Fusarium oxysporum colonizes the vascular system at the base of plants, limiting sap flow to infected stems (Holliday 1989).

In January and June 2003, we measured plant size. In January, plants grew as prostrate mats so we measured the diameter of these mats in perpendicular di- rections and from these measurements calculated mat area. In June, plants had bolted and possessed too many shoots to measure individually. We therefore estimated plant size by treating each plant as a cylinder, where $W_{1}$ and $W_{2}$ were the width of each plant in perpendicular directions and $H$ was the height of the tallest stem. Cylindrical volume $(V)$ was calculated as $V=\left(\left(W_{1}+\right.\right.$ $\left.\left.W_{2}\right) / 4\right)^{2} \times \pi \times(H)$. Volume is a good predictor of aboveground dry weight biomass $\left(R^{2}=0.67, P<\right.$ $0.0001, n=70$; J. L. Maron, unpublished data). In September, we harvested, dried (at $60^{\circ} \mathrm{C}$ until constant weight), and weighed all seed capsules from each plant. On a subset of plants, we counted as well as weighed seed capsules. Since capsule mass $m$ was strongly correlated to capsule number $\left(N ; R^{2}=0.90, n=46\right)$, we used the equation $N=m \times 69.09+124.87$ to convert capsule mass to capsule number.

\section{Data analysis-pathogen resistance}

For each population in each treatment we calculated the proportion of individuals that showed clear signs of pathogen infection and the proportion of those infected individuals that died. We then used two-way ANOVA (on arcsine transformed percentages) to determine how continent of origin, fungicide treatment, and the continent $\times$ treatment interaction influenced the percentage of plants that were infected or the percentage of infected plants that died in each population. In this statistical test, a significant continent effect indicates that across populations, infection differed based on continent of origin, as would be predicted if introduced plants from North America have lost resistance to pathogens. A significant treatment effect indicates that treating plants with fungicide affected the frequency of pathogen infection. The treatment $\times$ continent interaction tests whether the effect of treatment varied significantly among native and nonnative populations. Differences between populations could not be tested since we were examining differences in the percentage (rather than a mean number) of plants from each population that were infected (or died).

We also used two-way ANOVAs to determine how pathogen suppression (via fungicide treatment) and continent of population origin influenced plant size and fecundity. Both infected and noninfected plants in both treatments were used in this analysis. Factors were continent and treatment (fixed factors) and population nested within continent as a random factor. The interactions tested were continent $\times$ treatment and treatment $\times$ population nested within continent. This analysis revealed that fungicide treatment had an unexpected negative effect on size and fecundity, clouding our ability to detect any negative impact of pathogens on plant performance. To shed light on the potential negative impacts of pathogen infection on plant performance, we compared the size (log transformed) and fecundity of infected vs. noninfected control plants from each region, using separate nested ANOVAs (with both con- 

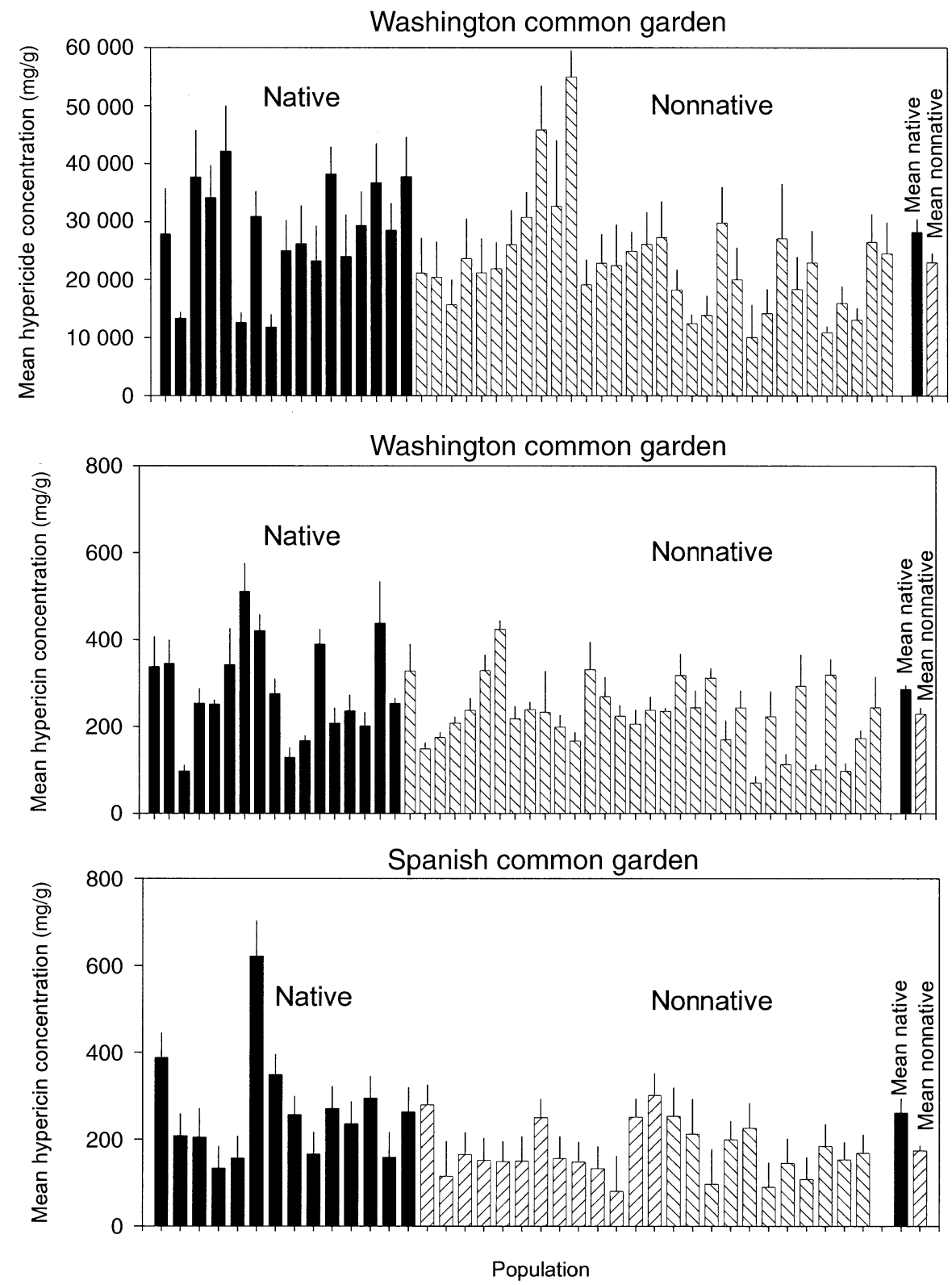

FIG. 1. Mean (+1 SE) concentration of hypericide and hypericin in native European (solid bars) and nonnative North American (striped bars) populations of St. John's Wort grown in the state of Washington, USA (top two panels) and in Spain (bottom panel).

tinent and population nested within continent as main effects).

\section{RESULTS}

\section{Variation in defensive chemistry}

Plants from North American populations had lower levels of defensive phytochemicals than plants from European populations in both Spain and Washington gardens. In Washington, North American plants produced, on average, $19 \%$ less hypericide, and $20 \%$ less hypericin, than European plants (Fig. 1a, b). These dif- ferences were either marginally (hypericin) or fully (hypericide) significant (Table 1). North American and European genotypes did not differ in pseudohypericin concentrations in Washington (Table 1). In Spain, North American $H$. perforatum had lower concentrations of both hypericin (Fig. 1c) and pseudohypericin compared to European genotypes (Table 1). In addition to differences between plants from the two continents, there were significant population-level differences in hypericin and pseudohypericin in Washington and Spain (Table 1). 
TABLE 1. Results from separate ANOVAs testing for the effect of continent of population origin and source population nested within continent on hypericin, hypericide, and pseudohypericin concentrations in St. John's Wort grown in Washington and Spain.

\begin{tabular}{|c|c|c|c|c|c|c|}
\hline \multirow[b]{2}{*}{ Source } & \multicolumn{4}{|c|}{ Hypericin } & \multicolumn{2}{|c|}{ Hypericide } \\
\hline & $\mathrm{df}$ & SS & $F$ & $P$ & $\mathrm{df}$ & SS \\
\hline \multicolumn{7}{|l|}{ Washington } \\
\hline Continent & 1 & 192251 & 3.6 & 0.065 & 1 & 1561470000 \\
\hline Population (continent) & 47 & 2522270 & 5.2 & 0.0001 & 47 & 24879800000 \\
\hline Error & 252 & 2602080 & & & 212 & 34499100000 \\
\hline \multicolumn{7}{|l|}{ Spain } \\
\hline Continent & 1 & 299104 & 11.1 & 0.002 & & \\
\hline Population (continent) & 37 & 997612 & 2.0 & 0.002 & & \\
\hline Error & 143 & 1895150 & & & & \\
\hline
\end{tabular}

In addition to genetically based differences in defensive compounds, across gardens, plants exhibited plastic responses in phytochemistry to variation in environmental conditions. In a more restrictive analysis comparing chemistry of clones grown in both gardens, concentrations of hypericin and pseudohypericin were significantly different depending on garden location. Concentrations of these compounds (e.g., mg hypericin or pseudohypericin per gram dry weight of plant material) were typically higher in plants grown in Spain than in Washington (across all populations, mean hypericin in Spain vs. Washington $=261 \mathrm{mg} / \mathrm{g}$ vs. 218 $\mathrm{mg} / \mathrm{g}$; mean pseudohypericin in Spain vs. Washington $=661 \mathrm{mg} / \mathrm{g}$ vs. $421 \mathrm{mg} / \mathrm{g}$; Table 2, post-hoc comparison, $P<0.05)$. As well, genotypes from North America consistently had reduced levels of hypericin in both gardens (mean across both gardens: $201 \mathrm{mg} / \mathrm{g}$ ) compared to native European genotypes (mean across both gardens: $246 \mathrm{mg} / \mathrm{g}$; Table 2). Levels of pseudohypericin did not differ between plants from native and introduced populations (Table 2). We found no significant continent of origin $\times$ garden interaction, indicating that the magnitude of plasticity for defensive chemistry was not different between native and introduced genotypes. However, the magnitude difference in secondary compounds among populations differed across gardens (as indicated by a significant population nested within continent $\times$ garden interaction; Table 2 ).

\section{Variation in pathogen resistance}

The first signs of pathogen infection appeared after plants had been in the field for one year. North Amer- ican populations had a significantly higher proportion of plants infected with pathogens than did European populations (Fig. 2a; ANOVA, $F_{1,56}=11.1, P<0.002$ ). Fungicide application significantly reduced pathogen infection; an average of $24 \%$ of the control plants in each population were infected vs. $13 \%$ of fungicidetreated plants (ANOVA, $F_{1,56}=14.8, P<0.004$ ). There was no significant treatment $\times$ continent interaction (ANOVA, $F_{1.56}=0.0005, P=0.98$ ) indicating that fungicide was equally effective at reducing pathogen attack on both North American and European genotypes.

North American plants suffered higher levels of mortality due to pathogen attack than did European plants (Fig. 2b; ANOVA, $F_{1,56}=4.6, P<0.04$ ). Mortality was $60 \%$ higher for North American vs. European control plants. Fungicide reduced mortality across all populations from an average of $14 \%$ to only $2 \%$, a significant difference (ANOVA, $F_{1,56}=32.2, P<0.0001$; Fig. 2b). There was no significant fungicide $\times$ continent interaction (ANOVA, $F_{1,56}=1.4, P=0.23$ ) indicating that fungicide reduced mortality due to infection by similar amounts for North American and European plants.

While fungicide reduced pathogen attack and pathogen-induced mortality, it also negatively affected plant size and reproduction (Fig. 3), probably by killing beneficial mycorrhizal fungi. Native European genotypes were more negatively affected by fungicide than were nonnative North American genotypes (as indicated by a significant treatment $\times$ continent interaction; ANOVA, $F_{1,28}=6.0, P<0.03$ for size and $F_{1,28}=4.3$,

TABLE 2. Results from ANOVA testing for effect of continent of population origin, source population nested within continent, and common garden location on hypericin and pseudohypericin concentrations in St. John's Wort.

\begin{tabular}{|c|c|c|c|c|c|c|c|c|}
\hline \multirow[b]{2}{*}{ Source } & \multicolumn{4}{|c|}{ Hypericin } & \multicolumn{4}{|c|}{ Pseudohypericin } \\
\hline & $\mathrm{df}$ & SS & $F$ & $P$ & $\mathrm{df}$ & SS & $F$ & $P$ \\
\hline Continent & 1 & 487642 & 7.8 & 0.008 & 1 & 253667 & 1.2 & 0.28 \\
\hline Population (continent) & 36 & 2252900 & 5.4 & 0.0001 & 36 & 7600390 & 6.1 & 0.0001 \\
\hline Garden & 1 & 141518 & 12.3 & 0.005 & 1 & 4580480 & 131.5 & 0.0001 \\
\hline Continent $\times$ garden & 1 & 13598 & 0.78 & 0.38 & 1 & 362263 & 0.18 & 0.67 \\
\hline Garden $\times$ population (continent) & 36 & 623474 & 1.5 & 0.04 & 36 & 2034330 & 1.6 & 0.02 \\
\hline Error & 334 & 3852200 & & & 334 & 1163420 & & \\
\hline
\end{tabular}


TABle 1. Extended.

\begin{tabular}{|c|c|c|c|c|c|}
\hline \multicolumn{2}{|c|}{ Hypericide } & \multicolumn{4}{|c|}{ Pseudohypericin } \\
\hline$F$ & $P$ & $\mathrm{df}$ & ss & $F$ & $P$ \\
\hline $\begin{array}{l}3.9 \\
2.9\end{array}$ & $\begin{array}{l}0.05 \\
0.09\end{array}$ & $\begin{array}{r}1 \\
47 \\
253\end{array}$ & $\begin{array}{r}101919 \\
9212390 \\
9009120\end{array}$ & $\begin{array}{l}0.52 \\
5.5\end{array}$ & $\begin{array}{l}0.47 \\
0.0001\end{array}$ \\
\hline & & $\begin{array}{r}1 \\
37 \\
143\end{array}$ & $\begin{array}{r}588188 \\
3601190 \\
354720\end{array}$ & $\begin{array}{l}6.0 \\
3.2\end{array}$ & $\begin{array}{l}0.02 \\
0.0001\end{array}$ \\
\hline
\end{tabular}

$P<0.05$ for fecundity). Because fungicide probably killed both beneficial and pathogenic fungi, comparing the performance of sprayed and unsprayed plants did not allow us to effectively isolate the impacts of pathogens on plant size and fecundity. We therefore performed an alternative analysis that only involved a comparison between control plants that showed signs of pathogen infection and those that did not. Infected plants had significantly reduced size (Fig. 4a; ANOVA, $F_{1,265}=13.1, P<0.0004$ ) and fecundity (Fig. 4b; ANOVA, $\left.F_{1,268}=8.1, P<0.0005\right)$ compared to uninfected plants. There was no overall difference between North American and European genotypes in size $\left(F_{1,28}=1.4, P=0.24\right)$ or fecundity $\left(F_{1,28}=0.34, P=\right.$ $0.58)$ nor were there significant continent $\times$ infection interactions $\left(F_{1,265}=0.21, P=0.64\right.$ and $F_{1,268}=1.7$, $P=0.20$ for size and fecundity, respectively). However, there were significant differences among populations in both size $\left(F_{28,265}=2.6, P<0.0001\right)$ and fecundity $\left(F_{28,268}=5.9, P<0.0001\right)$. The reduced size of infected compared to uninfected control plants could have been due to negative impacts of pathogens or a result of pathogens preferentially attacking small plants. To distinguish between these alternatives, we compared the size of uninfected individuals (prior to infection, in January) that later became infected with those that never became infected. Early in the season, uninfected control plants that later became infected by pathogens were actually larger than those that remained uninfected throughout the season (ANOVA, $F_{1,266}=$ 8.8, $P<0.004)$. However, there was no difference in early season size based on continent of origin (ANO$\left.\mathrm{VA}, F_{1,28}=1.5, P=0.24\right)$.

\section{DISCUSSION}

Our analysis of variation in defensive chemistry between European and North American St. John's Wort grown in Washington and Spain revealed three strong patterns. First, overall levels of defensive chemistry varied significantly from one common garden to the next. This is not surprising. Previous studies have found that concentrations of hypericin and pseudohypericin can be affected by season (Southwell and
Bourke 2001), population location (Walker et al. 2001), and nitrogen availability (Briskin et al. 2000). Second, levels of these compounds varied substantially among plants from different populations (Fig. 1). While levels of secondary compounds are often found to vary among individuals within populations, the basis for this variation is often unknown. If levels of defensive chemistry reflect past selection pressure imposed by herbivores and pathogens (McKey 1979, Berenbaum et al. 1986, Marquis 1992), our results suggest that there may be large differences between populations (both within Europe and North America) in the intensity of selection imposed by these pests. Furthermore, these results show that unlike some nonnatives (e.g., garlic mustard;
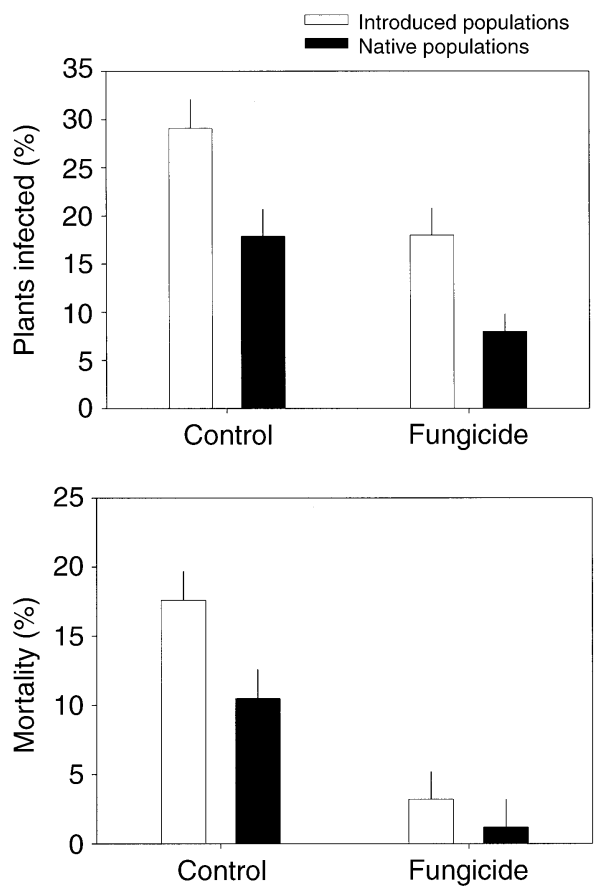

FIG. 2. Mean (+1 SE) percentage of individuals within introduced North American (open bars) and native European (solid bars) populations that were infected by pathogens (top panel) and that died after infection (bottom panel) in control or fungicide-treated plots within the Spanish common garden. 

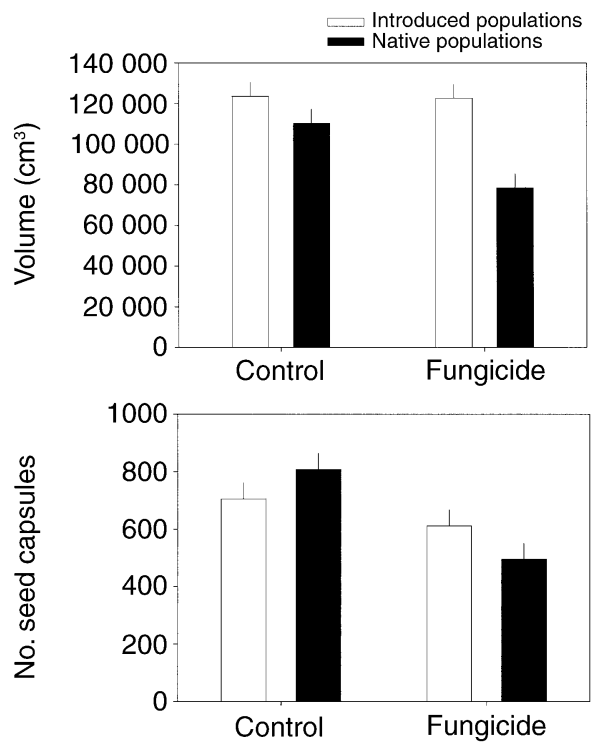

FIG. 3. Volume (top panel) and seed capsule production (bottom panel) of introduced North American (open bars) and native European (solid bars) plants in control or fungicidetreated plots within Spanish common garden. Bars are mean $(+1 \mathrm{SE})$ of population means.

Cipollini 2002), introduced St. John's Wort possesses substantial genetically based phenotypic variation in defensive chemistry. Third, and most importantly for testing the Evolution of Increased Competitive Ability (EICA) hypothesis, in addition to exhibiting substantial plasticity in secondary chemistry, introduced populations of St. John's Wort had genetically based reductions in defensive compounds relative to plants from native populations. North American genotypes had lower levels of hypericin in Spain and marginally significant reductions in hypericin in Washington, lower levels of hypericide (in Washington), and lower levels of pseudohypericin (in Spain only) than did plants from European populations.

There is some evidence that differences in defense between genotypes may be associated with ploidy (Pank et al. 2003). The majority of St. John's Wort individuals are pseudogamous apomicts, which are tetraploid. However, a small fraction of individuals are obligately sexual or reproduce by other means; these individuals can be diploids (Matzk et al. 2001, Pank et al. 2003). We do not know the ploidy of individuals sampled from different populations, so we cannot be certain that the differences in defensive chemistry we observed are not associated with changes in ploidy. However, we know of no evidence suggesting that there are systematic differences in ploidy between native and exotic genotypes. This is certainly an interesting line of future research.

Our comparison of patterns of pathogen infection and the impacts of several naturally occurring native pathogens on native and introduced genotypes grown in Spain provided a second test of whether introduced plants have lost enemy resistance. Here our results showed that a greater proportion of introduced genotypes suffered pathogen infection than did natives and that mortality due to pathogen attack was greater for introduced vs. native genotypes. In our first common garden in Spain, plants from western North America also had greater levels of what appeared to be pathogencaused mortality compared to native European genotypes (Maron et al. 2004).

In addition to increasing mortality, pathogen infection appeared to reduce plant size and fecundity. Control plants that exhibited clear signs of pathogen infection were smaller and produced fewer seed capsules than did control plants that showed no signs of infection. This was not due to small plants being more prone to pathogen attack than larger plants; in fact, the opposite was the case. Of course, a more robust approach to quantifying the effects of pathogens on plant size and fecundity would be to compare the performance of control vs. fungicide-treated plants. Unfortunately, this comparison was clouded by the fact that fungicide treatment had the unwanted effects of reducing plant size and fecundity. Since the fungicides we used had broad-spectrum effects, it seems likely that the fungicide treatment killed both pathogenic fungi as well as beneficial mycorrhizae (Newsham et al. 1994, Bayman et al. 2002). St. John's Wort is mycorrhizal (Klironomos 2002, 2003) and Benomyl can reduce populations of mycorrhizae (Callaway et al. 2001). Interestingly, European genotypes of St. John's Wort appeared more negatively affected by fungicide than were
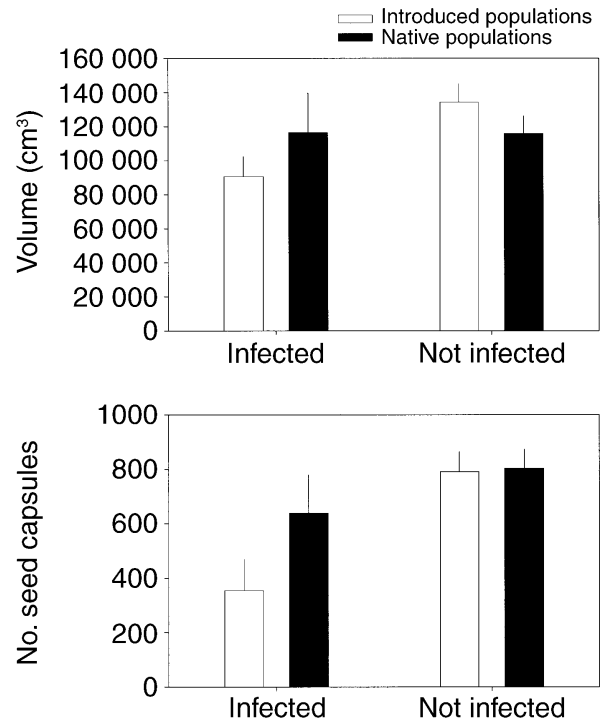

FIG. 4. Effect of pathogen infection on plant volume and seed capsule production for control plants from introduced North American and native European populations grown in Spain. Bars are mean $(+1 \mathrm{SE})$ of population means for plants either showing clear signs of pathogen infection or showing no signs of infection. 
North American genotypes, implying that perhaps the nonnative genotypes are less reliant on beneficial mycorrhizae than are native genotypes.

While in a general sense our results confirm one central prediction of the EICA hypothesis, the specific pattern of divergence in resistance between nonnative and native genotypes of St. John's Wort differs from what is predicted by EICA. EICA posits that introduced plants should lose resistance to specialist herbivores and pathogens, whereas the pathogens that attacked plants in Spain are generalists, and the defensive compounds we assayed for are also most effective at deterring generalist, as opposed to specialist, enemies (Sirvent et al. 2003). Furthermore, in ongoing work, we have found no difference between North American and European plants in resistance to a specialist insect herbivore, the biocontrol beetle Chrysolina quadrigemina (J. L. Maron and M. Vilà, unpublished data). It may be that selection by generalists in the native range has led to high levels of toxic qualitative defenses (Feeny 1976) among native St. John's Wort genotypes. In the introduced range, these defenses may no longer be at a selective premium. This underscores the fact that resistance (and its associated costs) against specialist vs. generalist enemies may differ, as will selection imposed by these different groups of enemies in both the native and introduced range. As such, it is unlikely that the simple situation envisioned by the EICA hypothesis, where only selection imposed by specialists differs between the native and introduced range, will universally apply. Future tests of EICA should consider how native and introduced genotypes differ in resistance to specialists as well as generalist enemies.

Work reported here is only a partial test of EICA; the hypothesis also posits that North American genotypes should be larger or more fecund than European conspecifics. In a previous test of this prediction involving common gardens in the United States (Washington and California), Spain, and Sweden, we found no difference in size and fecundity between North American and European H. perforatum (Maron et al. 2004). Similarly, in greenhouse experiments, we found no differences between North American and European plants in belowground biomass (S. C. Elmendorf, J. L. Maron, and M. Vilà, unpublished manuscript) or interspecific competitive ability (Vilà et al. 2003). In the present work, we again found no evidence that control plants from North America had greater aboveground size or fecundity compared to control plants from Europe (Fig. 4), although this comparison must be interpreted cautiously since large North American plants had a higher probability of subsequent pathogen attack than did smaller plants. In aggregate, however, results from this study and those reported elsewhere illustrate that reductions in natural enemy resistance do not necessarily lead to increases in plant size, fecundity, or competitive ability.
What mechanisms could cause the observed divergence in enemy defense between North American and European genotypes? We have previously shown, based on AFLP molecular markers, that there have been multiple introductions of St. John's Wort into North America, from many source localities throughout Europe (Maron et al. 2004). Thus, differences in phenotypes between North American and European plants are unlikely to be the result of a massive founder effect. Moreover, it is also unlikely that maternal effects play a substantial role in driving our results, since there are no significant differences in seed size between North American and European genotypes (J. L. Maron, unpublished data) and since we measured traits on older plants $(>1$ year old) that are often less influenced by maternal effects than young plants (Roach and Wulff 1987, Miao et al. 1991).

Given the lack of evidence for founder and maternal effects, it appears that introduced St. John's Wort may have undergone rapid genetically based changes in defensive traits in response to a novel biotic environment in the introduced range. Our results are not consistent with the Enemy Release Hypothesis, which posits that differences between native and exotic conspecifics in defensive chemistry are due solely to exotic plants plastically reducing their investment in defense in response to an enemy-free environment in their introduced range. To the extent that changes in defensive chemistry and pathogen resistance among North American populations are the product of evolution, it supports a growing body of work showing that organisms introduced into novel environments can evolve quickly (Reznick et al. 1997, Huey et al. 2000, Bone and Farres 2001, Lee 2002). These results complement our previous work showing that North American St. John's Wort may have also rapidly evolved adaptations to novel abiotic conditions across the introduced range (Maron et al. 2004). Taken as a whole, our research on St. John's Wort indicates that evolutionary processes should be increasingly incorporated into thinking about the ecology of invasions.

\section{ACKNOWLEDGMENTS}

We thank D. Ewing and P. Matas for greenhouse assistance in Washington and Spain, respectively. A. Agrawal, H. Auge, R. Callaway, S. Elmendorf, M. Kauffman, and D. Pearson provided helpful comments on the manuscript. R. Bommarco, B. Clifton, S. Elmendorf, D. Grosenbacher, J. Jones, T. Hirsch, T. Huettner, J. Pijoan, and M. Wolven helped establish and maintain the Washington common garden and $\mathrm{K}$. Parker graciously allowed us to establish research plots on her land. I. Gimeno and L. Marco helped to establish and maintain the Spanish common gardens. We thank A. Angert, D. Ayers, J. Combs, U. Gamper, S. Gardner, D. Greiling, F. Grevstad, J. Hess, R. Keller, P. Kittelson, E. Knapp, E. Ogheri, P. Pysek, A. Sears, R. Sobhian, A. Stanley, J. Taft, E. Weber, A. Weis, and A. Wolf for helping with seed collection. Students and staff at the University of Ottawa who assisted with the photochemical analysis included Andrew Knox, Alex Turcotte, Andrew Burt, and John Livesey. We also thank the "Servei de Laboratori de Sanitat Agraria" and J. Girbal for fungus 
identification. This work was supported by grants to JLM from the University of Washington Royalty Research Fund and from NSF grant DEB-0296175, and to MV from MCYT grant REN2000-0361 GLO.

\section{Literature Cited}

Andrés de, M. F., F. García-Arenal, M. M. López, and P. Megarejo. 1998. Patógenos de plantas descritas en España. Editorial del Ministerio de Agricultura, Pesca y Alimentación, Madrid, Spain.

Arnason, J. T., B. J. R. Philogene, and G. H. N. Towers. 1992. Phototoxins in plant-insect interactions. Pages 317-341 in G. A. Rosenthal and M. R. Berenbaum, editors. Herbivores: their interactions with secondary plant metabolites. Academic Press, New York, New York, USA.

Arnason, J. T., G. H. N. Towers, B. J. R. Philogene, and J. D. H. Lambert. 1983. The role of natural photosensitizers in plant resistance to insects. Pages 139-151 in A. Hedin, editor. Plant resistance to insects. ACS Symposium Series 208, American Chemical Society, Washington, D.C., USA.

Arnholdt-Schmitt, B. 2000. RAPD analysis: a method to investigate aspects of the reproductive biology of Hypericum perforatum L. Theoretical Applications in Genetics 100: 906-911.

Bayman, P., E. J. González, J. J. Fumero, and R. L. Tremblay. 2002. Are fungi necessary? How fungicides affect growth and survival of the orchid Lepanthes rupestris in the field. Journal of Ecology 90:1002-1008.

Bazzaz, F. A., N. Chiariello, P. D. Coley, and L. Pitelka. 1987. The allocation of resources to reproduction and defense. Bioscience 37:58-67.

Beckstead, J., and I. M. Parker. 2003. Invasiveness of Ammophila arenaria: release from soil-borne pathogens? Ecology 84:2824-2831.

Berenbaum, M. R., A. R. Zangerl, and J. K. Nitao. 1986. Constraints on chemical coevolution: wild parsnips and the parsnip webworm. Evolution 40:1215-1228.

Bergelson, J., and C. B. Purrington. 1996. Surveying patterns in the cost of resistance in plants. American Naturalist 148: 536-558.

Blossey, B., and R. Nötzold. 1995. Evolution of increased competitive ability in invasive nonindigenous plants: a hypothesis. Journal of Ecology 83:887-889.

Bone, E., and A. Farres. 2001. Trends and rates of microevolution in plants. Genetica 112-113:165-182.

Briskin, D. P., A. Leroy, and M. Gawienowski. 2000. Influence of nitrogen on the production of hypericins by St. John's Wort. Plant Physiology and Biochemistry 38:413420.

Callaway, R. M., B. Newingham, C. A. Zabinski, and B. E. Mahall. 2001. Compensatory growth and competitive ability of an invasive weed are enhanced by soil fungi and native neighbours. Ecology Letters 4:429-433.

Cipollini, D. 2002. Variation in the expression of chemical defenses in Alliaria petiolata (Brassicaceae) in the field and common garden. American Journal of Botany 89:14221430.

Crawley, M. J. 1997. Plant-herbivore dynamics. Pages 401474 in M. J. Crawley, editor. Plant ecology. Blackwell Scientific, Oxford, UK.

Daehler, C. C., and D. R. Strong. 1997. Reduced herbivore resistance in introduced smooth cordgrass (Spartina alterniflora) after a century of herbivore-free growth. Oecologia 110:99-108.

DeWalt, S. J., J. S. Denslow, and K. Ickes. 2004. Naturalenemy release facilitates habitat expansion of the invasive tropical shrub Clidemia hirta. Ecology 85:471-483.

Elton, C. S. 1958. The ecology of invasions. Methuen, London, UK.

Feeny, P. 1976. Plant apparency and chemical defense. Recent Advances in Phytochemistry 10:1-40.
Fields, P. G., J. T. Arnason, and B. J. R. Philogene. 1990. Behavioural and physical adaptations of three insects that feed on the phototoxic plant Hypericum perforatum. Canadian Journal of Botany 68:339-346.

Fitter, A. H., and R. Nichols. 1988. The use of benomyl to control infection by vesicular-arbuscular mycorrhizal fungi. New Phytologist 110:201-206.

Giese, A. C. 1980. Hypericism. Pages 229-255 in K. C. Smith, editor. Photochemical and photobiological reviews. Plenum Press, New York, New York, USA.

Holliday, P. 1989. A dictionary of plant pathology. Cambridge University Press, Cambridge, UK.

Huey, R. B., G. W. Gilchrist, M. L. Carlson, D. Berrigan, and L. Serra. 2000. Rapid evolution of a geographic cline in size in an introduced fly. Science 287:308-309.

Keane, R. M., and M. J. Crawley. 2002. Exotic plant invasions and the enemy release hypothesis. Trends in Ecology and Evolution 17:164-170.

Klironomos, J. N. 2002. Feedback with soil biota contributes to plant rarity and invasiveness in communities. Nature 417:67-70.

Klironomos, J. N. 2003. Variation in plant response to native and exotic arbuscular mycorrhizal fungi. Ecology 84:22922301.

Knox, J. P., and A. D. Dodge. 1985. Isolation and activity of the photodynamic pigment hypericin. Plant, Cell and Environment 8:9-25.

Lee, C. E. 2002. Evolutionary genetics of invasive species. Trends in Ecology and Evolution 17:386-391.

Mack, R. N., D. Simberloff, W. M. Lonsdale, H. Evans, M. Clout, and F. A. Bazzaz. 2000. Biotic invasions: causes, epidemiology, global consequences and control. Ecological Applications 10:689-710.

Maron, J. L., and M. Vilà. 2001. Do herbivores affect plant invasion? Evidence for the natural enemies and biotic resistance hypotheses. Oikos 95:363-373.

Maron, J. L., M. Vilà, R. Bommarco, S. Elmendorf, and P. Beardsley. 2004. Rapid evolution of an invasive plant. Ecological Monographs 74:261-280.

Marquis, R. J. 1992. The selective impacts of herbivores. Pages 301-325 in R. S. Fritz and E. L. Simms, editors. Plant resistance to herbivores and pathogens. University of Chicago Press, Chicago, Illinois, USA.

Matzk, F., A. Meister, R. Brutovská, and I. Schubert. 2001. Reconstruction of reproductive diversity in Hypericum perforatum L. opens novel strategies to manage apomixis. Plant Journal 26:275-282.

Mayo, G. M., and P. Langridge. 2003. Modes of reproduction in Australian populations of Hypericum perforatum L. (St. John's Wort) revealed by DNA fingerprinting and cytological methods. Genome 46:573-579.

McKey, D. 1979. The distribution of secondary compounds within plants. Pages 55-133 in G. A. Rosenthal and D. H. Janzen, editors. Herbivores: their interaction with secondary plant metabolites. Academic Press, New York, New York, USA.

Miao, S. L., F. A. Bazzaz, and R. B. Primack. 1991. Persistence of maternal nutrient effects in Plantago major: the third generation. Ecology 72:1634-1642.

Mitchell, C. G., and A. G. Power. 2003. Release of invasive plants from fungal and viral pathogens. Nature 421:625627.

Mitich, L. W. 1994. Intriguing world of weeds: common St. Johns Wort. Weed Technology 8:658-661.

Newsham, K. K., A. H. Fitter, and A. R. Watkinson. 1994. Root pathogenic and arbuscular mycorrhizal fungi determine fecundity of asymptomatic plants in the field. Journal of Ecology 82:805-814.

Packer, A., and K. Clay. 2000. Soil pathogens and spatial patterns of seedling mortality in a temperate tree. Nature 440:278-281. 
Pank, F., F. Matzk, U. Kästner, W. D. Blüthner, E. F. de Garcia, A. Meister, U. Ryschka, and G. Schumann. 2003. Reproductive diversity and strategies for breeding in St. John's Wort (Hypericum perforatum L.). Euphytica 134:77-84.

Reinhart, K. O., A. Packer, W. H. van der Putten, and K. Clay. 2003. Plant-soil biota interactions and spatial distributions of black cherry in its native and invasive ranges. Ecology Letters 6:1046-1050.

Reznick, D. N., F. H. Shaw, R. H. Rodd, and R. G. Shaw. 1997. Evaluation of the rate of evolution in natural populations of guppies (Poecilia reticulata). Science 275: 1934-1937.

Roach, D. A., and R. D. Wulff. 1987. Maternal effects in plants. Annual Review of Ecology and Systematics 18: 209-235.

Siemann, E., and W. E. Rogers. 2003. Reduced resistance of invasive varieties of the alien tree Sapium sebiferum to a generalist herbivore. Oecologia 135:451-457.

Sirvent, T. M., S. B. Krasnoff, and D. M. Gibson. 2003. Induction of hypericins and hyperforins in Hypericum perforatum in response to damage by herbivores. Journal of Chemical Ecology 29:2667-2681.

Smith, M. D., D. C. Hartnett, and C. W. Rice. 2000. Effects of long-term fungicide applications on microbial properties in tallgrass prairie soil. Soil Biology and Biochemistry 32 : 935-946.
Southwell, I. A., and C. A. Bourke. 2001. Seasonal variation in hypericin content of Hypericum perforatum L. (St. John's Wort). Phytochemistry 56:437-441.

Strauss, S. Y., J. A. Rudgers, J. A. Lau, and R. E. Irwin. 2002. Direct and ecological costs of resistance to herbivory. Trends in Ecology and Evolution 17:278-284.

SYSTAT. 2000. SYSTAT for Windows: statistics version 10.0. SPSS, Chicago, Illinois, USA.

Trifunovic, S., V. Vajs, S. Macura, N. Juranic, Z. Djarmati, R. Jankov, and S. Milosavljevic. 1998. Oxidation products of hyperforin from Hypericum perforatum. Phytochemistry 49:1305-1310.

Vilà, M., A. Gómez, and J. L. Maron. 2003. Are alien plants more competitive than their native conspecifics? A test using St. John's Wort (Hypericum perforatum). Oecologia 137:211-215.

Walker, L., T. Sirvent, D. Gibson, and N. Vance. 2001. Regional differences in hypericin and pseudohypericin concentrations and five morphological traits among Hypericum perforatum plants in the northwestern United States. Canadian Journal of Botany 79:1248-1255.

West, H. M., A. H. Fitter, and A. R. Watkinson. 1993. The influence of three biocides on the fungal associates of the roots of Vulpia ciliate ssp. ambigua under natural conditions. Journal of Ecology 81:345-350.

Wolfe, L. M. 2002. Why alien invaders succeed: support for the escape-from-enemy hypothesis. American Naturalist 160:705-711.

\section{APPENDIX}

Location of Hypericum perforatum seed source populations sampled in North America and Europe is available in ESA's Electronic Data Archive: Ecological Archives E085-111-A1. 